\title{
ÓDIO AO STF E ÀS UNIVERSIDADES PÚBLICAS: APLICA- ÇÃO DA ADPF 572 (CASO DAS FAKE NEWS) PARA PROTE- ÇÃO DA COMUNIDADE ACADÊMICA
}

HATE AGAINST STF AND PUBLIC UNIVERSITY: THE APPLICATION OF ADPF 572 (FAKE NEWS CASE) FOR THE ACADEMIC COMMUNITY PROTECTION"

\author{
Emanuel Melo Ferreira*
}

\section{RESUMO}

O presente artigo busca responder à seguinte indagação: é possível sustentar a aplicação do precedente firmado pelo Supremo Tribunal Federal no caso de Fake News (Inquérito 4781 e ADPF 572) em casos envolvendo ameaças, calúnia, injúria ou difamação contra grupos que compõem as Universidades? Tenta-se demonstrar como a ocorrência de crimes contra a honra contra grupos acadêmicos apresenta semelhança relevante em prol da aplicação do mencionado precedente, pois nele se buscava proteger juízes de ataques semelhantes. $O$ contexto de tais delitos é salientado a partir do autoritarismo populista com marcas anti-intelectuais, atraindo considerações em torno da democracia militante a partir da utilização de um precedente como mecanismo de defesa institucional também no contexto educacional. Conclui-se sustentando que as razões de decidir do precedente apontam mais semelhanças do que diferenças relevantes entre os casos, sendo correta a aplicação do precedente para as diversas situações envolvendo os direitos de alunos e de professores de tais instituições.

Palavras-chave: precedente; fake news; autoritarismo; anti-intelectualismo; universidades.

\section{ABSTRACT}

This article aims to answer the following question: is it possible to sustain the application of the Brazil's Supreme Court fake news precedent (Inquiry 4781 and ADPF 572) in cases involving calumny, injury or defamation against University groups? Seeks to demonstrate how crimes against academic groups' honor shows a relevant resemblance concerning the precedent application, because it had been formed to protect judges from similar attacks. The context of those crimes is highlighted through the populist-authoritarism whit anti-intellectual markers, bringing considerations concerning militant democracy and a precedent application as an institutional defense mechanism in the educational context. The text concludes that the rationes decidendi of the precedent shows that the similarities in the cases are more relevant than the differences, being correct its application on the variety of situations involving collective moral damages against students and professors of those institutions.

Keywords: precedent; fake news; authoritarism; antiintelectualism; universities.

\footnotetext{
* Doutorando em Direito, Constituição e Ordens Jurídicas pela Universidade Federal do Ceará (UFC). Mestre em Ordem Jurídica Constitucional pela UFC.

Professor Assistente I da Universidade do Estado do Rio Grande do Norte. Procurador da República.
}

emanuelmelo@uern.br 
INTRODUÇÃO; 1 A PROTEÇÃO AO REGIME DEMOCRÁTICO EXERCIDA PELO STF NA ADPF 572 NO CONTEXTO DA PRÁTICA DE CRIMES E DE DISSEMINAÇÃO DE FAKE NEWS; 20 ÓDIO À UNIVERSIDADE PÚBLICA COMO ESTRATÉGIA AUTORITÁRIA DE PODER; 3 A UTILIZAÇÃO DO PRECEDENTE FIRMADO NA ADPF 572 EM PROL DAS UNIVERSIDADES DIANTE DE SEMELHANÇAS RELEVANTES ENTRE OS CASOS; CONCLUSÃO; REFERÊNCIAS

\section{INTRODUÇÃO}

O presente artigo busca responder à seguinte indagação: é possível sustentar a aplicação do precedente firmado pelo Supremo Tribunal Federal na ADPF 572 aos casos de fake news envolvendo calúnia, injúria, difamação e ameaças contra grupos que compõem as Universidades? Em tal ação, pedia-se a declaração de inconstitucionalidade da Portaria GP no 69/2019, a qual, com base no art. 43 do Regimento Interno do Supremo Tribunal Federal (STF), instaurou inquérito para investigar a disseminação de fake news com potencial veiculação de crimes contra a honra e ameaças aos Ministros do Supremo Tribunal Federal. Não estava em jogo, assim, qualquer ofensa a estudantes ou professores universitários.

Por outro lado, o ensino público e, especialmente, as Universidades públicas brasileiras, têm passado desde 2019 por processo semelhante ao enfrentado pelo STF, pois são alvos constantes de forte campanha difamatória levada a cabo, por exemplo, pelo então Ministro da Educação Abraham Weintraub, o qual, reiteradamente, proferia declarações inverídicas contra tais instituições, tidas como locais de "balbúrdia" ou voltadas para plantação generalizada de maconha, com forte potencial discriminatório contra todos os membros da comunidade acadêmica. Além disso, os casos de ameaças envolvendo violência contra pesquisadores tem aumentado consideravelmente no Brasil, como será demonstrado adiante. Assim, o ódio ao ensino público deve ser compreendido a partir de estratégias intimidatórias que compõem a prática de crimes e disseminação de notícias fraudulentas contra alunos e professores.

Sendo assim, caso se demonstre a ocorrência de tais crimes e disseminação de notícias fraudulentas contra grupos acadêmicos, ter-se-á uma semelhança relevante em prol da aplicação do mencionado precedente do STF? Eis uma inquirição derivada diretamente da questão central acima posta. Além disso, é importante perquirir se as Universidades também são instituições essenciais para o Estado Democrático de Direito, especialmente quando se refere ao ensino público, capaz de gerar inclusão social. Caso seja assim, num Estado que se propõe a proteger direitos sociais a partir da Constituição de 1988, o enfraquecimento do ensino público equivale à instrumento de erosão democrática.

A pesquisa é relevante porque os precedentes, cada vez mais, apresentam importância prática no âmbito do Poder Judiciário, especialmente a partir da vigência do Código de Processo Civil de 2015. Diante da obrigatoriedade em torno da observância dos precedentes formados pelo STF no controle concentrado, o juiz fundamentará sua decisão de modo mais seguro sabendo que, dificilmente, ela será reformada nas demais instâncias, eis que lastreada num precedente da Corte. Essa análise realista da utilização dos precedentes por parte de, pelo menos, alguns juízes, justifica o esforço argumentativo desenvolvido nesta pesquisa pois, 
Ódio ao STF e às Universidades Públicas: aplicação da ADPF 572 (caso das fake News) para proteção da comunidade acadêmica

caso se comprovem as semelhanças entre os casos, a proteção judicial às Universidades restaria mais facilitada.

A pesquisa é, ainda, atual, pois alguns dos ataques às Universidades públicas já se encontram judicializados, como, por exemplo, tem-se em ação civil pública ajuizada pelo Ministério Público Federal na qual se busca a condenação da União em face dos danos morais coletivos praticados pelo referido Ministro da Educação quando, em tom generalizante, relacionou as Universidades a espaços de "balbúrdia" ${ }^{1}$, como dito.

Os referenciais utilizados na presente pesquisa partem da compreensão de que os precedentes merecem ser interpretados e não aplicados mecanicamente, como sustenta Ronald Dworkin ${ }^{2}$. Numa realidade autoritária como a brasileira, a interpretação dos precedentes deve potencializar a proteção ao regime democrático, sustentando-se tal tese a partir dos referenciais em torno da democracia militante.

O texto inicia apresentando os principais argumentos desenvolvidos pelos Ministros do STF no âmbito da mencionada ADPF, salientando como ela desenvolve um importante exercício em torno da democracia militante diante das omissões da Procuradoria Geral da República e da Polícia Federal. Em seguida, caracteriza-se o contexto autoritário no qual os diversos ataques às Universidades públicas são proferidos, para, finalmente, sustentar como há semelhanças relevantes entre os casos, havendo, assim, fortes razões para juízes também protegerem as Universidades contra campanhas de intimidação no exato contexto de proteção ao regime democrático.

\section{A PROTEÇÃO AO REGIME DEMOCRÁTICO EXERCIDA PELO STF NA ADPF 572 NO CONTEXTO DA PRÁTICA DE CRIMES E DE DISSEMINAÇÃO DE FAKE NEWS}

Em tal ADPF, pedia-se a declaração de inconstitucionalidade da Portaria GP no 69/2019, a qual, com base no art. 43 do Regimento Interno do Supremo Tribunal Federal (STF), instaurou inquérito para investigar a disseminação de fake news com potencial veiculação de crimes contra a honra e ameaças aos Ministros do Supremo Tribunal Federal. Para o Ministro Edson Fachin, relator do caso, a investigação presidida pelo Ministro Alexandre de Moraes do próprio STF no âmbito do inquérito 4781 merece continuar em face da gravidade que são os crimes contra a honra e ameaças proferidas contra os Ministros, os quais confundem-se com ataques à própria instituição, sendo capazes de fragilizar a democracia. Nessa linha, o STF, por $10 \times 1^{3}$, validou o Inquérito $\mathrm{n}-4.871$ e demonstrou a necessidade de se protegerem as instituições e os juízes da Corte. O Ministro reconhece que a mencionada norma do regimento

\footnotetext{
${ }^{1}$ BRASIL. Justiça Federal. Seção Judiciária do Rio Grande do Norte. 10a Vara Federal da Subseção Judiciária de Mossoró. Ação Civil Pública no 0800928-89.2019.4.05.8401.

2 DWORKIN, Ronald. Law's empire. Massachusetts: Harvard University Press, 1986. p. 53-54.

${ }^{3} \mathrm{O}$ voto vencido foi proferido pelo Ministro Marco Aurélio, para quem a respectiva norma regimental não fora recepcionada pela Constituição, tendo em vista a ofensa ao princípio acusatório. Além disso, a instauração do inquérito não foi obra do colegiado nem o respectivo relator fora escolhido mediante regular distribuição. BRASIL. Supremo Tribunal Federal. Medida cautelar na Arguição de descumprimento de preceito fundamental 572. Relator Ministro Edson Fachin. Julgamento em 18/06/2020.
} 
interno admite a cumulação da função judicante com a função investigativa, devendo-se justificar cuidadosamente as hipóteses em que a aplicação dela pode ocorrer, tendo em vista os impactos que tal procedimento ostenta ao princípio acusatório e à separação de poderes ${ }^{4}$.

Além disso, como estão em jogo delitos proferidos a partir de publicações na rede mundial de computadores, a análise judicial demanda atenção à liberdade de expressão, direito fundamental essencial ao debate público, mas que, por outro lado, exige também responsabilidade por parte daqueles que se manifestam publicamente. Assim, o Ministro Relator, expressamente, utiliza a democracia militante como referencial imprescindível para o deslinde da questão em termos de proteção do Estado de Direito democrático e dos Poderes instituídos. No ponto, realizara-se leitura da democracia militante para além da prática em torno do banimento de partidos políticos tidos como atentatórios ao regime democrático para albergar o enfrentamento de quaisquer "atos que, abusando dos direitos e garantias protegidos pela Constituição, invocando-os a pretexto de ideologia política, visam abolir ou restringir direitos de determinadas pessoas ou grupos" ${ }^{\prime \prime}$. Perceba-se a linguagem mais abstrata utilizada pelo Ministro, repetida por outros, como será demonstrado, associando os abusos em torno da liberdade de expressão como ofensa à democracia em si, não somente ao Poder Judiciário.

A partir dessa leitura da democracia militante, o Ministro sustenta claramente que não estão protegidas pela liberdade de expressão manifestações que levem ao desrespeito às decisões judiciais, sendo inadmissíveis no "Estado de Direito democrático, portanto, a defesa da ditadura, do fechamento do Congresso Nacional ou do Supremo Tribunal Federal. Não há liberdade de expressão que ampare a defesa desses atos" 6 .

Um dos aspectos mais relevantes em torno do fenômeno das fake news refere-se à respectiva utilização em massa nas redes sociais, com sofisticados esquemas de financiamento e divulgação, como salientado pelo STF no caso quando limitou a decisão às hipóteses com essas características ${ }^{7}$. De acordo com o Tribunal, os atos praticados apontam para: a) incitamento ao fechamento do STF; b) ameaças de morte e de prisão dos respectivos membros; c) desobediência às decisões da Corte ${ }^{8}$. Dentre as fake news criadas contra os Ministros da Corte, destaca-se: a) a suposta vinculação de 8 Ministros do STF com o tráfico internacional de drogas; b) a divulgação de inexistente conversa envolvendo o Ministro Alexandre de Moraes, o qual estaria tramando um ataque a Brasília com utilização de sniper. ${ }^{9}$

\footnotetext{
${ }^{4}$ BRASIL. Supremo Tribunal Federal. Medida cautelar na Arguição de Descumprimento de Preceito Fundamental no 572. Relator Ministro Edson Fachin. Julgamento em 18/06/2020. Voto Ministro Edson Fachin.

${ }^{5}$ Idem. p. 28-29.

${ }^{6}$ Ibidem.

$7 \mathrm{O}$ próprio objeto da investigação estipulado no Inquérito 4.781/DF demonstra a preocupação com a disseminação de notícias fraudulentas em massa: "investigação de notícias fraudulentas (fake news), falsas comunicações de crimes, denunciações caluniosas, ameaças e demais infrações revestidas de animus caluniandi, diffamandi ou injuriandi, que atinjam a honorabilidade institucional do SUPREMO TRIBUNAL FEDERAL e de seus membros, bem como a segurança destes e de seus familiares, quando houver relação com a dignidade dos Ministros, inclusive com a apuração do vazamento de informações e documentos sigilosos, com o intuito de atribuir e/ou insinuar a prática de atos ilícitos por membros da Suprema Corte, por parte daqueles que tem o dever legal de preservar o sigilo; e a verificação da existência de esquemas de financiamento e divulgação em massa nas redes sociais, com o intuito de lesar ou expor a perigo de lesão a independência do Poder Judiciário e ao Estado de Direito". Ibidem. p. 34.

8 Ibidem. p.1.

${ }^{9}$ Ibidem. p. 263-264.
} 
Ódio ao STF e às Universidades Públicas: aplicação da ADPF 572 (caso das fake News) para proteção da comunidade acadêmica

Além de notícias fraudulentas, o referido inquérito busca proteger a Corte diante de crimes de ameaça sofridos por seus membros. Assim, o que se tem, de acordo com os trechos transcritos no voto do Ministro Alexandre de $\operatorname{Moraes}^{10}$, são crimes de injúria e ameaça contra Ministros e seus familiares, com indicação de planos para ataque em aeroportos, a partir do prévio conhecimento da agenda pública deles. Chega-se a sugerir, até mesmo, a vestimenta para a abordagem criminosa: "Ir de terninho quer dizer que é estudante de direito para inflar o ego desses porcos. Ai sim será uma grande coisa." ${ }^{11}$

Além disso, deve-se destacar a estratégia utilizada em tais ambientes virtuais, quando se constata a participação de um agente que tenta instigar a prática de crimes nos demais participantes de fóruns na deepweeb. No trecho transcrito no voto, é possível perceber o interesse em manipular outras pessoas, sugerindo-se recompensas a título honorífico ${ }^{12} \mathrm{com} o$ cometimento de crime contra os Ministros, como se houvesse uma espécie de causa a ser defendida e o STF fosse um obstáculo à transformação pretendida. Em outra fala, tem-se a crença de que, uma vez preso em alguma "base do Exército" após o cometimento do crime, lá seria "tratado como um verdadeiro heroi"13. Obviamente, são falas com alguma imagem de grandeza e desconhecimento a ponto de supor que eventual custódia cautelar seria cumprida em instalação militar mas, de todo modo, é revelador do pensamento acerca das Forças Armadas que alguns extremistas ostentam. $\mathrm{O}$ recurso às ideias quase primatas, referindo-se às

\footnotetext{
${ }^{10}$ Exemplos de ameaças e crimes contra a honra praticados contra os Ministros podem ser vistos no voto do Ministro Alexandre de Moraes, nestes termos: "que estuprem e matem as filhas dos Ordinários Ministros do STF (postagem realizada da rede social Facebook por advogada do Rio Grande do Sul, sugerindo e instigando aqueles que não concordem com decisões proferidas pelos Ministros desta CORTE devem resolver essas pendências usando de violência e com o cometimento de crimes hediondos)".

Quanto custa atirar a queima roupa nas costas de cada ministro filho da puta do STF que queira acabar com a prisão da segunda instância? Se acabarem com a prisão em segunda instância, só nos resta a jogar combustível e tocar fogo no plenário do STF com ministros Barbies dentro.

ataques cibernéticos nos e-mails institucionais. Ameaças a membro da Corte e seus familiares: Já temos em nosso poder armas e munição de grosso calibre (...) esconda seus filhos e parentes bem escondido na Europa porque aqui você não vai ter aonde se esconder, o inferno e a revolta vai cair sobre sua cabeça (...) Fazemos um tribunal em Praça pública com direito a fuzilamento de todos os parasitas e vagabundos estatais que se acham Deuses $\mathrm{Na}$ terra, como os Vagabundos ordinários dos seus colegas ministros, que são autoritários e Mentirosos. (...) vai se fuder desgraça, fica aí perseguindo pessoas inocentes, quer uma ameaça real?? Ta aí o papo reto no texto acima, você vai ser jogada na lata do lixo principalmente depois do seu Voto sobre prisão em segunda instância, isso aí já é motivo pra pegarmos em armas e fazer revolução armada contra todos vocês. Fique esperta e cuide bem dos seus parentes porque nós vamos ser sua sombra.
}

o arremesso de "artefato explosivo" de dentro de um veículo automotor, que explodiu em frente a casa de Ministro desta CORTE, tendo sido integralmente filmado pela câmera de segurança do condomínio." (Ibidem, p. 133-137)

11 Ibidem. p. 134.

12 O criminoso seria tido, na verdade, como "heroi": "Usuário Sanctvs - Tem que olhar a agenda pública de ministros do STF. Quando forem viajar é só esperar no saguão do aeroporto antes dos detectores de metais. Ir de terninho quer dizer que é estudante de direito para inflar o ego desses porcos. Ai sim será uma grande coisa. Resposta de outro usuário: Isso não é difícil, apenas use o conhecimento. Pense muito antes de agir. Vê uma viagem que demora para chegar, assim dá tempo de planejar, quem conseguir eliminá-lo seria um herói." Ibidem. p. 134,

13 "Igualmente, na DeepWeb e nesse mesmo site conversas e imagem da planta baixa do STF e planos para invasão e atentados a Ministros " Se eu ainda tiver uma oportunidade eu mato esse TERRORISTA filho de um repositório de esperma. Caso eu seja preso eu provavelmente serei mantido em uma base do Exército e com certeza eu seria tratado como um verdadeiro herói lá dentro e eu me sentiria orgulhoso de ter feito justiça com as minhas próprias mãos e de entrar para a historia deste país ". Ibidem. p. 136 
práticas violentas em tribos africanas em conflito também foi encontrado ${ }^{14}$, no contexto de como a suposta associação criminosa atua através do twitter, buscando posicionar-se nos temas mais comentados, os trend topics, com o auxílio dos respectivos seguidores ${ }^{15}$.

Uma das críticas centrais ao inquérito 4781 refere-se à ofensa ao princípio acusatório. $\mathrm{Na}$ argumentação desenvolvida nos mais diversos votos proferidos acerca do tema, a linha de raciocínio desenvolvida parte da constatação de que: a) o MP não é o único órgão legitimado para realizar investigações, fazendo com que a titularidade da ação penal não se converta em possibilidade de elidir diligências investigativas efetivadas por outros órgãos; b) a PGR, posteriormente, manifestou-se nos autos, sendo tal acompanhamento suficiente para afastar a ofensa ao princípio acusatório, pois a titularidade da ação penal pública resta preservada com a decisão do MP em denunciar ou não ${ }^{16}$.

A autodefesa institucional como componente da democracia militante foi destacada em diversos votos, como uma espécie de legítima defesa ${ }^{17}$. Para o Relator, a tese capaz de

\footnotetext{
14 “Usuário Sanctvs - Já ouvi dizer que na África quando uma tribo queria provocar uma outra tribo eles pegavam o mais novo da tribo rival e matava. Pode se aplicar a mesma ideia com o ministro se não for possível pegar ele podemos ir atrás de alguém da família dele. Vamos colocar essa ideia em prática confrades. Alguém descobre algum endereço desses animais". Ibidem. p. 134.

15 "Conforme apresentado anteriormente, os perfis influenciadores iniciam os ataques selecionando um tema, por exemplo, o Impeachment de membros do STF. Nesta etapa inicial estes perfis não necessariamente utilizam uma hashtag para disseminar o ataque escolhido, valendo-se muitas vezes de seus seguidores (followers) para criar uma hashtag e impulsionar este ataque. Desta forma, os perfis influenciadores não apareceriam como criadores da hashtag que simboliza o ataque. (...) Conforme exposto os perfis influenciadores identificados, iniciaram seus ataques a partir do dia 07/11/2019, declarando que o STF é uma vergonha e clamando por pedidos de impeachment de seus membros, sem necessariamente utilizar a hashtag \#ImpeachmentGilmarMendes . Em seguida, seus seguidores passaram a compartilhar e comentar estas publicações, introduzindo a hashtag em questão. Finalmente, no dia 11 de novembro de 2019, 10 (dez) destes perfis influenciadores adotam a hashtag \#ImpeachmentGilmarMendes neste mesmo dia, de forma aparentemente coordenada, impulsionando ainda mais a adoção desta hashtag por seus seguidores de forma que esta alcançasse o Trend Topics da rede social Twitter. Uma vez que uma hashtag alcança o Trend Topics, sua visualização é ampliada significativamente para fora da bolha, alcançando muitos outros usuários, que não são seguidores dos influenciadores iniciais." Ibidem. p. 161.

${ }^{16}$ Ibidem. p. 50-51; 64; 116; 122-125; 144; 167; 198-199; 239-241; 276-277; 289-290; 333-334.

17 Ibidem. p. 174; 226-227; 268; 312-313; 356; 367. Como, por exemplo, constata-se no voto do Ministro Luis Roberto Barroso: “Portanto, eu penso que é isso em grande medida que está em discussão nesta ação que nós estamos a julgar: saber qual a extensão do poder de legítima defesa das instituições e particularmente de uma Suprema Corte diante dos ataques concertados que possam estar sofrendo. Sempre lembrando que, muitas vezes, o caminho para aquelas democracias iliberais é um caminho que passa pelo desprestigiamento das instituições intermediárias que fazem uma mediação entre o poder e a sociedade, como a imprensa, o Legislativo ou o Judiciário. Quando se saltam os canais de intermediação, vai-se diretamente ao povo via rede sociais, e quando essas redes sociais, por vontade própria ou instigadas, atacam aquelas instituições intermediárias, estáse abrindo o caminho para a concentração do poder e para a erosão democrática". Ibidem. p. 174. Sobre a interpretação da norma regimental que fundamenta a instauração do IPL no contexto da defesa institucional diante das omissões do MPF ou da Polícia Federal, o Ministro Edson Fachin sustenta que: "É, pois, um instrumento de defesa da própria Constituição e, se o juiz não tem ordinariamente essa função, a defesa institucional a reclama se houve inércia ou omissão dos órgãos de controle. É sob essas luzes constitucionais que devem ser interpretados os dispositivos regimentais que fundam o ato impugnado. Nem de longe, no entanto, sentidos ou práticas podem implicar violação à própria Constituição e seus preceitos fundamentais. A defesa institucional que pode legitimar o artigo $43 \mathrm{em}$ pauta tem cabimento restrito às hipóteses de inércia ou omissão de atuação própria do Ministério Público ou mesmo da polícia judiciária, e se limita a bens jurídicos institucionais. É que não há (nem pode haver) defesa da Constituição contra a Constituição. A defesa institucional há de ser, sempre, nas balizas da legalidade constitucional". Ibidem. p. 57.
} 
Ódio ao STF e às Universidades Públicas: aplicação da ADPF 572 (caso das fake News) para proteção da comunidade acadêmica

justificar a excepcionalidade do referido inquérito poderia ser assim caracterizada: "O desenho constitucional também inscreveu na República brasileira a proteção do Estado de Direito democrático e por isso mesmo dos Poderes instituídos, razão pela qual a preservação das instituições é essencial na democracia representativa"18.

Em outros trechos, fica clara a justificativa para a instauração do inquérito levando em conta a omissão dos órgãos de controle em tal tarefa. Os Ministros Edson Fachin, Gilmar Mendes e Dias Toffoli, por exemplo, destacaram o papel subsidiário que uma investigação conduzida pelo próprio STF deveria ostentar, precisamente diante da inércia do MPF e da Polícia Federal ${ }^{19}$ Nesse sentido, a então PGR Raquel Dodge chegou a promover o arquivamento de tal inquérito, desenvolvendo argumentação que corresponde à mencionada crítica à investigação, eis que não iniciada a pedido do Ministério Público, tendo sido tal pleito rejeitado pelo Ministro Alexandre de Moraes, eis que o MP não tem a exclusividade da investigação penal ${ }^{20}$. O PGR Augusto Aras, por outro lado, demonstrou comportamento contraditório na condução do caso. Inicialmente, divergiu da posição de Raquel Dodge e atuou no inquérito, chegando a se manifestar previamente em diligências. No entanto, logo após deferimento de medidas

\footnotetext{
18 Ibidem. p. 51.

19 Ibidem. p. 56; 281-285; 358; 378. Assim sustenta o Ministro: “Quanto a esse relevante papel subsidiário de investigação criminal, registro que, embora a Procuradoria-Geral da República esteja vindicando o protagonismo sobre a apuração dos fatos ocorridos no Inquérito 4.781, é importante destacar que o Ministério Público Federal, em diversos casos de ataques sofridos pelo Tribunal ou constatados nos processos julgados por esta Corte, não adotou as providências cabíveis. Nessa linha, diversas manifestações de agentes públicos e particulares, com a incitação à prática de atos inconstitucionais e antidemocráticos, como o fechamento desta Corte e até mesmo a prisão ou destituição dos Ministros de suas funções, não foram objeto da devida atenção por parte da PGR até a instauração do inquérito pelo Tribunal. As próprias ameaças à vida e à integridade física dos Ministros e seus familiares, que constituem o objeto do Inquérito 4.781, não foram anteriormente apuradas pelo Parquet, embora já ocorressem com alguma frequência e sistematicidade, a indicar a realização de atos coordenados por pessoas unidas por interesses escusos. Corroborando essa afirmação, destaco alguns dados obtidos pela Presidência desta Corte que registram a comunicação de crimes cometidos contra o Tribunal e seus membros que não foram devidamente apurados: Ofício n 003766/2018: Registro de ocorrência em frente à residência do Ministro Lewandowski em São Paulo, no dia 30 de março de 2018. Nessa oportunidade, manifestantes estavam colocando fogo em bonecos que representavam os Ministros desta Corte, atirando ovos contra a residência do Ministro e praticando outros atos semelhantes. A então Presidente desta Corte, Ministra Cármen Lúcia, encaminhou os fatos ao Diretor-Geral da Polícia Federal em 6 de abril de 2018. Não houve retorno a respeito de providências adotadas pela Polícia Federal quanto ao caso.

Ofício no 003412/2018: Registro de agressão contra o Ministro Gilmar Mendes em Portugal. Representação feita pelo próprio Ministro ao Diretor-Geral da Polícia Federal. Foram solicitadas informações junto à Polícia Federal, que se limitou a dizer que, em 24 de maio de 2019, estava em fase final de diligências. A Polícia Federal não prestou novas informações após esse último contato.

Ofício no 007210/2018: Registro de declaração de Procuradora da República, que teria afirmado que o STF estava a serviço de bandidos. A então Presidente encaminhou ofício à PGR em 13 de julho de 2018. A PGR respondeu ao ofício dizendo que foi aberto procedimento no CNMP. Não há registro de sanção aplicada à Procuradora.

Ofício no 013021/2018: comunicação de agressão verbal contra o Ministro Lewandowski em voo comercial. O Ministro Toffoli enviou ofício à PGR em 5 de dezembro de 2018. Não houve qualquer retorno quanto a eventuais providências adotadas. Em 11 de outubro de 2019, tendo em vista a ausência de providências pela PGR, os fatos foram encaminhados para o inquérito das fake news.

Ofício no 013215/2018: registro de ameaça de bomba no STF por e-mail. Foi encaminhado ofício ao DGPF em 11 de janeiro de 2019. Há registro apenas de que foi aberto inquérito policial, sem informação sobre o número e sem informações posteriores quanto ao andamento do inquérito". Ibidem. p. 283-285.

${ }^{20}$ Ibidem. p, 144.
} 
cautelares contra parlamentares do Partido Social Liberal, sustentou a necessidade de suspender o inquérito ${ }^{21}$. Essa postura do Ministério Público é determinante para justificar a militância democrática exercida pelo STF no caso, como será abordado adiante.

O fenômeno da desinformação recebe cada vez mais atenção, especialmente na era digital em que se vive e "um dos principais problemas associados às Fake News é o seu impacto na dinâmica democrática" ${ }^{22}$. Nesse cenário, há desacordo acerca de como as desinformações devem ser enfrentadas, havendo quem defenda o sancionamento estatal através, por exemplo, do direito penal em face de quem produz ou divulga tais materiais como modo de se preservar a democracia. Por outro lado, os críticos de tais medidas utilizam a liberdade de expressão para se contrapor a tais medidas, apontando como elas violam tal direito fundamental essencial à própria democracia. Assim, a democracia acaba sendo utilizada tanto por defensores como opositores à regulamentação das fake news ${ }^{23}$.

É importante caracterizar adequadamente o fenômeno da desinformação. Nesse sentido, novamente, veja-se o que Clarissa Groos sustenta:

\begin{abstract}
As Fake News seriam, portanto, um tipo novo de conteúdo produzido a partir de uma intencionalidade apenas viabilizada pelo modelo de produção, disseminação e consumo de conteúdo online. Trata-se do conteúdo mentiroso, ou seja, intencionalmente falso, fabricado com o objetivo de explorar as circunstâncias do universo online (o anonimato, a rapidez na disseminação da informação, a fragmentação das fontes de informação e da atenção dos usuários da Internet, e o apelo às emoções e ao sensacionalismo) para fins de obtenção de vantagens econômicas ou políticas. Ainda, além de intencionalmente falso, esse conteúdo seria fraudulento por ser disponibilizado de tal maneira a imitar o formato da mídia tradicional ${ }^{24}$.
\end{abstract}

Sem dúvidas que própria a possibilidade de debate público de ideias é "uma exigência contextual da democracia" ${ }^{25}$. A qualidade do debate público e as falsidades apontam que a circunstância de que, caso se admita que a liberdade de expressão é um instrumento para o debate público de qualidade, fica difícil admitir a proteção de falsidades ${ }^{26}$. Essa concepção instrumental da liberdade de expressão, vista como um meio para se garantir o debate público de qualidade, apesar de importante, é insuficiente para que se estabeleça adequadamente a configuração constitucional de tal direito. Assim, vista como liberdade em si, a liberdade de expressão é também um direito individual, ou seja, protegido em termos não consequencialistas, pouco importando seu real impacto no regime democrático e no debate público.

Assim, reconhecendo a liberdade de expressão como elemento constitutivo da democracia, tem-se que ela é valorizada como direito, não se exigindo, por exemplo, a comprovação de opiniões ou algum tipo de esclarecimento prévio como condição para o discurso de alguém ser admitido, o qual pode ser, até mesmo, irracional. Do contrário, ter-se-ia um

\footnotetext{
${ }^{21}$ Ibidem. p, 13-14.

22 GROSS, Clarissa Piterman. Fake news e democracia: discutindo o status normativo do falso e a liberdade de expressão. In.: RAIS, Diogo (org.). Fake news - a conexão entre a desinformação e o direito. 2o ed. São Paulo: Thomson Reuters Brasil, 2020. Posição 2206.

${ }^{23}$ GROSS, Clarissa Piterman. Op. cit. Posição 2223-2239.

24 GROSS, Clarissa Piterman. Op. cit. Posição 2271.

25 GROSS, Clarissa Piterman. Op. cit. Posição 2321.

${ }^{26}$ GROSS, Clarissa Piterman. Op. cit. Posição 2391.
} 
Ódio ao STF e às Universidades Públicas: aplicação da ADPF 572 (caso das fake News) para proteção da comunidade acadêmica

elitismo e uma desigualdade inadmissíveis ${ }^{27}$. Pode-se dizer que, em regra, "a exclusão do debate público baseada no juízo de pouco valor das informações, opiniões e crenças das pessoas é uma violação da igualdade"28.

Por outro lado, mesmo a concepção constitutiva de liberdade de expressão e sua importância em si para a democracia não pode admitir proteção a qualquer tipo de falsidade. Assim,

a liberdade política não implica uma série de práticas de má-fé porque não faz sentido afirmar que as pessoas possuem o direito de se enganar de forma maliciosa para fins de obtenção de vantagens políticas ou econômicas. A igualdade política não protege, portanto, a intenção de fraudar o debate público. ${ }^{29}$

A fim de não se caracterizar ofensa à liberdade de expressão, com imposição de inibições ou intimidações ao debate público, deve-se perquirir pela má-fé ${ }^{30}$ no desenvolvimento do discurso, ou seja, no conhecimento doloso acerca da falsidade desenvolvida, no caso das notícias fraudulentas. Em situações nas quais, por exemplo, um Ministro de Estado da Educação faz afirmações inverídicas logo em relação ao tema da sua pasta, no contexto de diversas outras medidas que atingem a educação pública, como será demonstrado, é possível comprovar a vontade deliberada, livre e consciente em manipular a verdade para atingir os grupos universitários. O mesmo poderia ser dito de alguém que, artificialmente, cria um áudio com a suposta voz de Ministro do STF para vinculá-lo a práticas criminosas.

É a partir do cenário antes descrito pelo STF que a Corte buscou sustentar a necessidade de um exercício de democracia militante para preservar a instituição, tida como essencial ao regime democrático. A democracia militante, democracia defensiva ou a democracia combativa correspondem a um conjunto de medidas preventivas que um regime democrático esteja disposto a recorrer para evitar que forças autoritárias subvertam a democracia através de meios democráticos, tendo sido desenvolvido pela primeira vez por Karl Loewenstein nos anos $1930^{31}$.

Assim, lançando as origens em torno da ideia de democracia militante, Loewenstein analisa duas hipóteses mutualmente exclusivas acerca do declínio democrático e da possibilidade de reação democrática. Caso se admita que o fascismo é uma espécie de crença em valores absolutos que, funcionando como uma espécie metafísica de "espírito" mostra-se como algo inevitável e com vitória histórica certa, não há como se impedir ou reverter o declínio democrático. Caso se constate, por outro lado, que a democracia não cumpriu ainda seu papel, sendo o fascismo mais uma técnica de poder do que uma crença, ou seja, sendo algo superável e evitável, a democracia pode reagir, mas ela tem de se tornar militante ${ }^{32}$.

\footnotetext{
27 GROSS, Clarissa Piterman. Op. cit. Posição 2540.

28 GROSS, Clarissa Piterman. Op. cit. Posição 2556.

${ }^{29}$ GROSS, Clarissa Piterman. Op. cit. Posição 2606.

${ }^{30}$ Tal teste é amplamente admitido, citando-se como precedente o caso New York Times Co. v. Sullivan. New York Times Co. v. Sullivan, 376 U.S. 254, 1964.

${ }^{31}$ MÜLLER, Jan-Werner. Militant democracy. In: ROSENFELD, Michel; SAJÓ, András. (ed.). The Oxford Handbook of Comparative Constitutional Law. Oxford: Oxford University Press, 2012, p. 1253-1269. p. 1254.

32 LOEWENSTEIN, Karl. Militant democracy and fundamental rights $I$. The American political science review. Vol. XXXI. № 3. Jun. 1937. p. 422-423.
} 
A medida mais extrema em termos de democracia militante refere-se ao banimento de partidos políticos com tendências extremistas ${ }^{33}$. Assim, a justificação em torno da exclusão do debate de certas ideias no espaço público é o ponto de partida fundamental de uma teoria da democracia militante para que se diferencie uma real medida de autoproteção democrática de um mero ataque às ideias contra as quais não se concorda ${ }^{34}$. 0 tema se impõe a partir da necessidade de se teorizar acerca de como a democracia pode se proteger sem, nesse percurso, ajudar na sua própria autodestruição, com a transformação de liberais nos próprios tiranos que se deseja derrotar, nesse contexto de paradoxo democrático ${ }^{35}$. Este parece ser o dilema central: a proporcionalidade dos meios de defesa da democracia. Sustenta-se que buscar a responsabilização de pessoas as quais, após exercerem o direito fundamental à liberdade de expressão, abusam de tal direito, não equivale à corrupção da democracia em autoritarismo, mas sim na própria proteção daquela, no caso de as autoridades de controle, como a Procuradoria Geral da República, restarem comprometidas diante de captura institucional por parte do Poder Executivo.

A justificativa em torno da democracia militante como apta a debelar o extremismo é uma das hipóteses possíveis, atraindo a dificuldade em se identificar precisamente em que consiste o extremismo. Há receio de que as ideias tidas por extremistas sejam aquelas defendidas mais à esquerda, quando, por outro lado esteja-se, simplesmente, defendendo um outro tipo de democracia, mesmo que radicalmente diferente ${ }^{36}$. No âmbito do direito constitucional, crítica semelhante em torno das dificuldades práticas da democracia militante também é efetivada por Davi Landau. Para o autor, tal militância pode apresentar alguma eficácia em face da atuação preventiva contra os clássicos partidos políticos com tendências extremistas, como o nazista, sendo mais difícil conceber sua aplicação diante de ameaças ambíguas e não ideológicas como aquelas em torno do constitucionalismo abusivo ${ }^{37}$. A primeira e uma das mais importantes questões, então, é descrever precisamente em que consistem essas novas práticas autoritárias, questionando a afirmação de Landau acerca do caráter não ideológico delas: na verdade, parece ser essencial compreender em que consiste essa atual ideologia autoritária para corretamente enfrentá-la, tendo-se em vista um parâmetro constitucional

\footnotetext{
${ }^{33}$ Para Bastiaan Rijpkema, essa é a medida mais extrema em termos de democracia militante e, caso se consiga justificá-la, a justificação de outras medidas menos drásticas, como o banimento de símbolos ou a exclusão de antidemocratas de cargos públicos, restará mais facilitada, podendo-se compartilhar muitos dos argumentos, em princípio. RIJPKEMA, Bastiaan. Militant democracy. The limits of democratic tolerance. London, New York: Routledge, 2018. P. 5 No Brasil, a Constituição de 1988 alberga militância democrática quando disciplina o regime jurídico dos partidos políticos, os quais devem zelar pela democracia e pelos direitos humanos, nos termos do art. 17, bem como quando determina a criminalização de ações de grupos civis ou militares contra o estado democrático de direito, de acordo com o art. 5‥ XLIV.

${ }^{34}$ RIJPKEMA, Bastiaan. Militant democracy. The limits of democratic tolerance. London, New York: Routledge, 2018. p. 4.

35 Idem.

${ }^{36}$ Ibidem. p. 1267.

${ }^{37} \mathrm{O}$ constitucionalismo abusivo corresponde à utilização de mecanismo constitucionais, especialmente as emendas constitucionais ou a própria substituição de uma Constituição por outra, para erodir o próprio regime democrático por dentro, com a alteração de mandatos presidenciais ou mudanças na composição das Cortes Constitucionais. Um regime afetado por tais mudanças não é propriamente uma ditadura, pois ainda existem as eleições e não se recorre a um golpe no modelo clássico, com características militares e violentas. Ele se distancia, no entanto, paulatinamente, de uma melhor democracia para se aproximar de modelos autoritários, como se tem na Venezuela ou na Hungria. LANDAU, David. Abusive constitutionalism. Davis Law Review. University of California. Vol. 47. 2013. p. 189-260. p. 189.
} 
Ódio ao STF e às Universidades Públicas: aplicação da ADPF 572 (caso das fake News) para proteção da comunidade acadêmica

democrático. Como será abordado adiante, uma das marcas centrais do autoritarismo atual é o anti-intelectualismo, expressado, precisamente, no contexto de ataques às universidades.

Buscando evitar os abusos em torno da aplicação da democracia militante, estes seriam os critérios a serem seguidos pelo Judiciário, destacando-se o caráter da sistematicidade e do não isolamento dos atos em si: a) análise em torno das visões extremistas em jogo, as quais busquem, permanentemente, excluir ou retirar o poder de parcela do povo democraticamente integrado; b) ataque sistemático à dignidade de grupos que fazem parte do povo na democracia; c) compreensão de que os proponentes das visões extremistas claramente assemelham-se aos antigos genocidas; d) eles buscam falar em nome de todo o povo, sistematicamente negando as fraturas e divisões na sociedade ou o controle dos demais poderes ${ }^{38}$. No contexto da campanha difamatória contra o ensino público universitário, a característica elencada no item "b" mostra-se como a mais saliente, pois falas como a do Ministro da Educação buscam negar a diversidade acadêmica, criticando manifestações que vão de encontro à visão de mundo dele, a qual não é plural.

Após essa análise, é possível sustentar que o STF adotou postura generalizante em seus fundamentos decisórios, preocupando-se com a democracia como um todo em face da disseminação de ataques sistemáticos e falsos às instituições. Como será demonstrado adiante, em momento algum, por exemplo, a Corte adotou alguma espécie de formulação linguística canônica restringindo a aplicação do precedente aos estritos ataques ao Poder Judiciário. Sendo assim, nos exatos limites em torno da democracia militante expressamente consignada pela Corte, é possível sustentar a tese ora defendida.

Após a leitura de todo o acórdão, é possível constatar que a preocupação central do STF na validação no inquérito refere-se aos mencionados crimes praticados contra os Ministros, bem como à disseminação de notícias fraudulentas. Em algumas passagens dos Votos, no entanto, é possível constatar falta de clareza sobre supostos "ataques" à Corte ${ }^{39}$, cuja menção genérica deve ser cuidadosamente analisada para que tal precedente, no futuro, não seja utilizado com finalidades autoritárias, ou seja, para intimidar o livre exercício das ideias no debate público. Esse temor deve ser levado muito a sério, mas não se pode confundir as situações: o STF ateve-se muito mais às ameaças concretas e detalhadas e à disseminação de notícias fraudulentas, sendo equivocado, portanto, sustentar que o precedente tende a provocar efeito silenciador no debate público. Além disso, a militância democrática exercida pela STF foi excepcional, como salientado em diversos trechos dos votos acima elencados, diante da omissão dos órgãos de controle, como Ministério Público e Polícia Federal. Especificamente

\footnotetext{
${ }^{38}$ MÜLLER, Jan-Werner. Militant democracy. In: ROSENFELD, Michel; SAJÓ, András. (ed.). The Oxford Handbook of Comparative Constitutional Law. Oxford: Oxford University Press, 2012, p. 1253-1269. p. 1267.

${ }^{39}$ Por exemplo, tal passagem do Voto do Ministro Dias Toffoli não é precisa: "Nesse mesmo dia, o Plenário do Supremo Tribunal Federal concluía o julgamento do Agravo Regimental no Inquérito no 4.435, de relatoria do Ministro Marco Aurélio, no qual esta Corte, por maioria, confirmou jurisprudência anterior no sentido da competência da Justiça Eleitoral para processar e julgar crimes comuns que apresentam conexão com crimes eleitorais. Antes e durante esse julgamento, houve uma série de ataques nas redes sociais contra a Corte e seus Ministros, e também contra a Justiça Eleitoral, inclusive por parte de operadores do sistema de justiça, jogando parte da população e parte da imprensa contra o STF e a Justiça Eleitoral." Ibidem. p. 356-357. Quais foram esses "ataques"? Como saber se não se tratou de correto exercício da liberdade de expressão, mesmo que duramente exercido? Nesse ponto, o receio com a citada decisão deve ser levado a sério, quando se critica a decisão em comento diante da possibilidade de ofensas à liberdade de expressão. No entanto, esse risco não decorre do precedente do STF, mas de sua má aplicação, como dito.
} 
no caso no inquérito em questão, a instituição que mais deveria ser cobrada diante de omissões inconstitucionais que auxiliam na erosão democrática brasileira é o Procuradoria Geral da República, não o STF ${ }^{40}$.

\section{0 ÓDIO À UNIVERSIDADE PÚBLICA COMO ESTRATÉGIA AUTORITÁRIA DE PODER}

O Poder Executivo Federal tem adotado diversas medidas as quais auxiliam para que se comece a caracterizar corretamente as marcas autoritárias da política brasileira atual, em termos educacionais: a) bloqueio de orçamento imposto às instituições de ensino em todo o país em $30 \%$ dos recursos pelo Ministério da Educação a instituições federais de ensino superior, a partir dos Decretos presidenciais 9.725/2019 e 9.794/2019, ferindo o princípio da separação de Poderes e a autonomia universitária na sua tríplice vertente: didático-científica, administrativa e de gestão financeira e patrimonial ${ }^{41}$; b) ofensa aos alunos e professores por partes de Ministro da Educação ${ }^{42}$; c) ao interesse de o Governo Federal em intervir nas referidas instituições a partir da nomeação de reitores sem o devido processo de escolha, em manifesta ofensa à autonomia universitária ${ }^{43}$; d) encerramento da política de quotas raciais nos programas de pós-graduação ${ }^{44}$.

Esses atos fazem parte de um contexto mais amplo em torno dos atuais modelos autoritários que se desenvolvem em diversas partes do mundo, como no Brasil, a partir dos quais o enfraquecimento do conhecimento produzido nas universidades é uma das marcas centrais, pois o apelo exacerbado à emoção em detrimento da razão é uma das marcas de regimes que podem ser considerados populistas. É difícil caracterizar precisamente em que consiste o referido populismo, mas os lugares comuns normalmente elencados na definição compreendem uma "inerente hostilidade aos mecanismos e, em última análise, aos valores comumente associados com o constitucionalismo: limitações à vontade da maioria, freios e contra pesos, proteção às minorias e aos direitos fundamentais como tais" 45 .

Sendo, centralmente, um movimento antipluralista ${ }^{46}$ ao ter como reivindicação central o argumento de que o líder populista é o único que pode representar os autênticos interesses

\footnotetext{
${ }^{40}$ Com isso não se quer dizer que o STF não tenha participação na erosão democrática brasileira, adotando diversas decisões que a desestabilizaram, a partir, por exemplo, da demora em controlar os excessos da operação Lava Jato. MEYER, Emílio Peluso Neder. Judges and Courts Destabilizing Constitutionalism: The Brazilian Judiciary Branch's Political and Authoritarian Character. German Law Journal. Vol. 19 , ed. 4. 2018. p. 727-768.

${ }^{41}$ ADI 6127, pendente de julgamento perante o Supremo Tribunal Federal.

${ }^{42}$ Conforme processado pelo Ministério Público Federal na ação civil pública citada.

${ }^{43}$ Medida Provisória no 979/2020.

${ }^{44}$ Portaria 545 do Ministério da Educação, ato editado pelo então Ministro da Educação Abraham Weintraub pouco antes de sua exoneração.

${ }^{45}$ MÜLLER, Jan-Werner. Populism and constitutionalism. In: OSTIGUY, Pierre el al (ed.). The Oxford Handbook of Populism. Oxford: Oxford University Press, 2017. P. 744.

46 Mostrando como se trata de um movimento global, Ferrajoli descreve como o autoritarismo populista que busca levar a cabo um processo de desconstrução constitucional tem tomado corpo na Itália, com semelhanças com o caso brasileiro. Para o autor, a Constituição italiana de 1948 tem sido atacada por inimigos que a acusam de uma velhice que leva à não governabilidade, tendo os direitos fundamentais sido sistematicamente atacados pelos detentores de poder, agora exercidos de modo selvagem, sem controle ou respeito às regras. A dimensão substancial da democracia, aquela decorrente da positivação dos direitos fundamentais, é tida como menos im-
} 
Ódio ao STF e às Universidades Públicas: aplicação da ADPF 572 (caso das fake News) para proteção da comunidade acadêmica

das pessoas, negando por completo o próprio status de concidadão àqueles que lhe são críticos, tidos como inimigos ${ }^{47}$. Assim, o populismo é visto como movimento mais próximo da democracia direta, havendo uma ligação mais direta entre a liderança e parcela do povo, em detrimento das instituições, as quais podem ter se tornado muito elitistas, mas somente na exata medida em que elas não se mostrem aptas a produzir resultados correspondentes à moral do líder, tida como a única correta ${ }^{48}$.

No contexto autoritário no qual se nega o pluralismo, como o faz, precisamente, quem utiliza discurso falso para atacar as universidades, tem-se que estas "devem ser enfraquecidas e cooptadas para difundir a ideologia prevalente na visão da política fascista. Nega-se, por exemplo, que as universidades sejam espaços da liberdade de expressão porque ecoariam apenas uma voz política, a da esquerda" ${ }^{49}$.

Jason Stanley aponta que uma das características da política fascista, é, precisamente, o anti-intelectualismo ${ }^{50}$ o qual manifesta-se sob diversos meios a partir de ataques diretos ao ensino com: a) cortes orçamentários não justificados ${ }^{51}$; b) expurgo de professores tidos como inimigos $^{52}$; c) proibição de discussão de questões de gênero ou relacionadas às minorias em geral $^{53}$. Além desses fatos, é possível vislumbrar a prática de crimes contra a honra envolvendo professores e alunos, vítimas de preconceito e disseminação de notícias falsas sobre a vida acadêmica, com a intenção de enfraquecê-la. Contra este último fato também deve-se ter a devida atenção, pois o combate a tal prática em termos de dano moral coletivo merece ser analisado com uma das possibilidades para reprimir exemplarmente discursos desse tipo, cabendo à parcela democrática do Ministério Público, por exemplo, a tarefa de buscar essa reparação através da ação civil pública.

portante ou superável pela dimensão formal, relacionada às eleições para cargos políticos. Os inimigos do constitucionalismo no aspecto material sustentam suas ações como democráticas a partir dessa vontade da maioria que os elegeu e o consequente respeito pelo aspecto formal da democracia. (FERRAJOLI, Luigi. Poderes selvagens. A crise da democracia italiana. Tradução de Alexander Araujo de Souza. São Paulo: Saraiva, 2014. posição 168-184) O populismo intolerante é assim caracterizado pelo autor: “A ideia elementar que está na base desta pretensão é que o consenso popular é a única fonte de legitimação do poder político e serviria, portanto, para legitimar todos os abusos e para deslegitimar críticas e controles. O inteiro edifício da democracia constitucional fica em razão disso minado à sua raiz: pela intolerância em relação ao pluralismo político e institucional; pela desvalorização das regras; pelos ataques à separação de poderes, às instituições de garantia, à oposição parlamentar, aos sindicatos e à liberdade de imprensa; pela rejeição, em síntese, do paradigma do Estado constitucional de direito como sistema de vínculos legais impostos a qualquer poder". (FERRAJOLI, Ob. cit. posição 155)

${ }^{47}$ MÜLLER, Jan-Werner. Populism and constitutionalism. In: OSTIGUY, Pierre el al (ed.). The Oxford Handbook of Populism. Oxford: Oxford University Press, 2017. p. 745; 749.

${ }^{48}$ MÜLLER, Jan-Werner. Populism and constitutionalism. In: OSTIGUY, Pierre el al (ed.). The Oxford Handbook of Populism. Oxford: Oxford University Press, 2017. P. 744; 754.

${ }^{49}$ MEYER, Emilio; BUSTAMANTE, Thomas; BATISTA JÚNIOR, Onofre Alves. Autonomia universitária, democracia e federalismo. Revista Culturas Jurídicas. Vol. 6, Núm. 13, jan./abr., 2019. p. 286. Continuam os autores: “Não se trata de uma coincidência que os espantalhos que embasam o certo às universidades seja os chamados 'marxismo cultural' ou 'doutrinação marxista'. Universidades, espaços naturais do pluralismo (inclusive semanticamente), tornam-se centros 'perigosos' porque dão voz a perspectivas marginalizadas, algo que a política fascista abomina." Ob. cit. p. 287.

50 STANLEY, Jason. Como funciona o fascismo: a política do "nós" e "eles". Tradução de Bruno Alexander. São Paulo: L\&PM, 2018. p. 34.

${ }^{51}$ ADI 6127, pendente de julgamento perante o Supremo Tribunal Federal, como dito.

52 Caso ocorreu no caso da Turquia. STANLEY, Jason. Ob. Cit. p. 47.

53 Caso da "escola sem partido", prática julgada unanimemente inconstitucional pelo STF na Arguição de descumprimento de preceito fundamental no 457. Relator Ministro Alexandre de Moraes. 27/04/2020. 
A relação entre fascismo e populismo, no contexto mais amplo do autoritarismo, precisa ser bem delineado, pois, os autores utilizam as mais diversas denominações para caracterizar os movimentos de recessão democrática no mundo ${ }^{54}$. Nesse sentido, Federico Finchelstein sustenta que fascismo e populismo devem ser compreendidos historicamente no sentido de este ser uma espécie de continuação daquele, tendo o populismo moderno nascido do fascismo, consistindo este numa forma autoritária de democracia ${ }^{55}$. Com o genocídio e a violência exacerbada da política fascista do século XX, tal ideologia política perdeu legitimidade como forma de governo, de modo que "não estamos assistindo ao regresso do fascismo como este existiu antes" 56 . Sendo assim, embora interligados, fascismo e populismo "representam trajetórias políticas e históricas alternativas" 57 , sendo "o populismo uma forma de democracia autoritária, enquanto o fascismo é uma ditadura ultraviolenta" ${ }^{58}$ pois o populismo busca legitimar-se pelas eleições, adaptando o fascismo à democracia a partir de um ataque aos ideais iluministas efetivado especialmente a partir do fim da segunda guerra mundial ${ }^{59}$.

\footnotetext{
${ }^{54}$ A caracterização de um regime como autoritário apresenta certas complexidades à medida em que se constata que a crise atual em diversas democracias não decorre majoritariamente da ocorrência de clássicos golpes de estados militares, mas da formação de espécies de modelos híbridos, situados entre a democracia e ditadura, mantendo-se eleições periódicas mas utilizando os próprios mecanismos democráticos formais para subverter a democracia substancial, atacando fortemente, por exemplo, grupos minoritários. Tem-se, assim, um processo de erosão constitucional, em oposição às bruscas mudanças ocorridas em situações de colapso. (GINSBURG, Tom; HUQ, Aziz Z.; How to save a constitutional democracy. Chicago; London: The University of Chicago Press, 2018.) Diversos estudos já têm sido efetivados em torno do constitucionalismo abusivo (LANDAU, David. Abusive constitutionalism. Davis Law Review. University of California. Vol. 47. 2013), do constitucionalismo autoritário (TUSHNET, Mark. Authoritarian constitutionalism. Cornell Law Review. Vol. 100. 2015), bem como da relação entre a mencionada crise da democracia e a emergência de um constitucionalismo populista (MüLLER, Jan-Werner. Populism and constitutionalism. In: OSTIGUY, Pierre el al (ed.). The Oxford Handbook of Populism. Oxford: Oxford University Press, 2017) ou da própria superação da democracia em face do neoliberalismo com a formação de "estados pós-democráticos" (CASARA, Rubens R. R. O estado pós-democrático: neo-obscurantismo e gestão dos indesejáveis. Rio de Janeiro: Civilização Brasileira, 2017. Kindle Edition).

${ }^{55}$ FINCHELSTEIN, Federico. Do fascismo ao populismo na história. Tradução Jaime Araújo. São Paulo: Almedina, 2019. Kindle edition. posição 78; 159.

${ }^{56}$ FINCHELSTEIN, Federico. Ob. cit. posição 52.

${ }^{57}$ FINCHELSTEIN, Federico. Ob. cit. posição 78.

${ }^{58}$ FINCHELSTEIN, Federico. Ob. cit. posição 281.

59 “Nesse sentido: Uma nova modernidade populista surgiu com a derrota do fascismo. Depois da guerra, o populismo reformulou os legados do "anti-lluminismo" para a era da Guerra Fria e pela primeira vez na história tornou-se completo; ou seja, alcançou o poder. Em 1945 o populismo já passara a representar uma continuação do fascismo, mas também uma rejeição de alguns dos seus aspetos ditatoriais mais distintivos. O fascismo propôs uma ordem totalitária violenta que conduziu a formas extremas de violência política e genocídio. Em contrapartida, e em consequência da derrota do fascismo, o populismo procurou reformar e adaptar o legado fascista a uma ordem democrática. Depois da guerra, o populismo foi uma consequência do impacto civilizacional do fascismo. A ascensão e queda dos fascismos afetaram não só admiradores como o general Juan Perón na Argentina, mas também outros líderes autoritários como Getúlio Vargas no Brasil, ou muitos membros da direita populista americana que não tinham vivido nem concordado inicialmente com o fascismo. Para alcançar o poder, o populismo do pós-guerra renunciou aos seus fundamentos pró-ditatoriais do período entreguerras mas não abandonou completamente o fascismo. Ocupou o lugar do fascismo transformando-se numa nova "terceira via" entre o liberalismo e o comunismo. No entanto, ao contrário dos apoiadores do fascismo, seus proponentes queriam que o populismo fosse uma escolha democrática. Essa intenção populista de criar uma nova tradição política que pudesse governar a nação mas fosse diferente do fascismo, e a realização consequente dessa intenção, explicam a complexa natureza histórica do populismo populismo do pós-guerra como um conjunto variado de experiências autoritárias na democracia. É verdade que o populismo moderno integrou elementos de outras tradições, mas as origens e efeitos fascistas do populismo depois da derrota de Hitler e Mussolini definiram o seu conflito constitutivo pós-fascista entre a democracia e a ditadura". (FINCHELSTEIN, Federico. Ob. cit. posição 92-105)
} 
Ódio ao STF e às Universidades Públicas: aplicação da ADPF 572 (caso das fake News) para proteção da comunidade acadêmica

Ataques coordenados às Universidades, como marca anti-intelectual, servem para desvalorizar a educação, buscando-se legitimar um discurso autoritário em torno de uma única concepção de vida no espaço público:

A política fascista procura minar o discurso público atacando e desvalorizando a educação, a especialização e a linguagem. É impossível haver um debate inteligente sem uma educação que dê acesso a diferentes perspectivas, sem respeito pela especialização quando se esgota o próprio conhecimento e sem uma linguagem rica o suficiente para descrever com precisão a realidade. Quando a educação, a especialização e as distinções linguísticas são solapadas, restam somente poder e identidade tribal.

Isso não significa que não haja um papel para as universidades na política fascista. $\mathrm{Na}$ ideologia fascista, há apenas um ponto de vista legítimo: o da nação dominante. As escolas apresentam aos alunos a cultura dominante e seu passado mítico. A educação, portanto, representa uma grave ameaça ao fascismo ou se torna um pilar de apoio para a nação mítica60"

O populismo, ainda, não se preocupa com a verdade empiricamente demonstrada, sendo essa característica uma das mais importantes, pois também é a partir de disseminação de notícias falsas e de difamação contra as universidades que o anti-intelectualismo vai se manifestar:

Os populistas não se preocupam muito com as sutilezas da observação empírica, mas dirigem antes a sua atenção para a reformulação, ou mesmo a reinvenção, da realidade de acordo com seus vários imperativos ideológicos. Viver dentro da bolha populista permite aos líderes, regimes e seus seguidores apresentar tudo o que não gostam como mentiras da mídia e conspirações internas e externas contra o povo, o líder e a nação. Nesse aspecto, o populismo relaciona-se diretamente com a recusa clássica do fascismo em determinar a verdade empiricamente" ${ }^{61}$

Assim, pode-se dizer que a irracionalidade tem papel decisivo na configuração de modelos autoritários, pois compõe a essência do processo político, sendo as teorias anti-intelectualistas um caminho para os golpes de estado ${ }^{62}$. Nesse sentido, Francisco Campos criticava a empreitada liberal de buscar conformar a democracia à imagem do mundo forense, como se a deliberação pública fosse resultado de um choque de argumentos entre as partes de um processo judicial perante o magistrado. Tal imagem do processo político é equivocada porque desconsidera a irracionalidade da massa, a qual emerge na esperança de fazer uma aclamação por um líder carismático, um César, que vá governar ditatorialmente ${ }^{63}$. 0 autor é claro: “o regime político das massas é a ditadura", pois quanto maior a massa, mais a integração política se torna possível somente através de uma vontade pessoal ${ }^{64}$.

Assim, enquanto liberalismo e socialismo, em algum momento, terão de enfrentar seus equívocos, o populismo simplesmente nega os seus e, quando confrontado com eles,

\footnotetext{
${ }^{60}$ STANLEY, Jason. Ob. cit. p. 36.

${ }^{61}$ FINCHELSTEIN, Federico. Ob. cit. posição 132-146.

${ }^{62}$ CAMPOS, Francisco. O estado nacional. Coleção Biblioteca Básica Brasileira. Brasília: Senado Federal, Conselho Editorial, 2001. p. 19; 26.

${ }^{63}$ CAMPOS, Francisco. Ob. Cit. p. 24-26.

${ }^{64}$ CAMPOS, Francisco. Ob. Cit. p. 23.
} 
transforma seu interlocutor em tirano ${ }^{65}$ ou inimigo do povo. As relações entre fascismo e populismo apontam que neste a violência contra opositores mostra-se mais como uma ferramenta retórica, sendo estes tratados como inimigos do povo. Quando o estágio da demonização dos opositores ainda não evoluiu para qualquer ato efetivo de perseguição, tem-se um modelo populista. Quando, no entanto, “o populismo passa dessa inimizade retórica para práticas de identificação e perseguição dos inimigos, podemos estar falando da sua transformação em fascismo ou em outra forma de repressão ditatorial" 66 .

Esse avanço em torno da identificação de inimigos, com políticas concretas de perseguição, começa a ser desenvolvido no âmbito da educação brasileira, seja no que tange ao mencionado "corte de gastos" nas universidades, seja na ameaça de se "caçar um pessoal que fica fazendo balbúrdia"67, seja na ameaça de punição a professores que exercem o direito constitucional de reunião. ${ }^{68}$ Apesar de fatos graves, eles ainda se inserem no âmbito da retórica exaltada a qual, de modo algum, merece ser contemporizada, mas combatida pelas instituições, como o $\mathrm{MPF}^{69}$, para que se busque evitar, precisamente, a transformação descrita por Finchelstein do populismo para o fascismo.

Uma proposta de caracterização do autoritarismo que ressalta seu aspecto falsificador, ou seja, como algo dotado de uma estrutura mais profunda que busca se mostrar como democrático a partir de uma estratégia subliminar é proposta por Gábor Attila Tóth. Para ele, o autoritarismo hodierno demonstra-se a partir de marcos que correspondem: a) num primeiro nível, à análise estrutural das práticas constitucionais, do papel das eleições, do controle entre os Poderes e da aplicação dos direitos fundamentais; b) num segundo nível, à utilização de justificações falsas para a tomada de certas medidas que, aparentemente, podem ser descritas por seus apoiadores como democráticas ${ }^{70}$. A compreensão em torno da fraude argumentativa é de suma importância para caracterização desses atuais modelos na medida em que, como dito, não se tem um golpe militar clássico ou ausência de eleições como critérios mais claros para identificar um regime autoritário, o qual, neste caso, aproximar-se-ia de uma ditadura.

Não é novidade alguma a aparência de normalidade democrática que regimes autoritários buscam ostentar, como se tem em torno da "legalidade autoritária" após o golpe militar

\footnotetext{
65 FINCHELSTEIN, Federico. Ob. cit. posição 146.

${ }^{66}$ FINCHELSTEIN, Federico. Ob. cit. posição 269.

${ }^{67}$ A fala foi efetivada por Abraham Weintraub no contexto de representação recebida em face de atos praticados na UFSC. Disponível em: https://g1.globo.com/sc/santa-catarina/noticia/2019/10/25/em-video-ministro-daeducacao-diz-que-vai-cacar-um-pessoal-da-ufsc-que-fica-fazendo-balburdia.ghtml. Acessado em: 15/07/2020.

${ }^{68}$ Disponível em: http://portal.mec.gov.br/component/tags/tag/35487. Acessado em: 15/07/2020.

${ }^{69}$ No caso dos protestos mencionado na nota anterior, o MPF emitiu recomendação para que o Ministério da Educação cancelasse a nota em que desautorizava a divulgação de protestos. Disponível em: http://www.mpf.mp.br/pgr/noticias-pgr/mpf-da-prazo-de-dez-dias-para-que-mec-cancele-nota-em-que-

desautoriza-divulgacao-de-protestos. Acessado em: 15/07/2020. No entanto, o MPF precisa lidar também com membros que não ostentam respeito pelo regime democrático, pois, em resposta à mencionada recomendação, fora expedida outra sustentando o acerto da nota do MEC: http://www.mpf.mp.br/go/sala-deimprensa/noticias-go/mpf-recomenda-ao-mec-que-disponibilize-canais-para-receber-denuncias-sobre-atos-denatureza-politico-partidaria-realizados-em-predios-de-instituicoes-publicas-de-ensino. Acessado em: 15/07/2020.

70 TÓTH, Gábor Attila. Constitutional Markers of Authoritarianism. Hague Journal on the Rule of Law, v. 11, n. 1, 2019. P. 55-56.
} 
Ódio ao STF e às Universidades Públicas: aplicação da ADPF 572 (caso das fake News) para proteção da comunidade acadêmica

brasileiro, na expressão de Anthony Pereira71, a partir da qual se tem "manipulação jurídica", com a utilização do Direito para as finalidades autoritárias. Neste caso, no entanto, a análise é mais restrita à análise de processos judiciais como instrumento para perseguição de dissidentes num contexto de ditadura militar, com a manutenção de uma espécie de integração e cooperação entre o governo e juízes para que estes emprestem a respeitabilidade da decisão judicial como forma de legitimar a política desenvolvida.

Por outro lado, o que é salientado por Tóth é a utilização de argumentações viciadas na tomada da decisão, vício este mais difícil de ser caracterizado e exposto por ser utilizado como se fosse algo razoável, dentro de comprometimentos democráticos, oferecendo a liberdade de expressão um exemplo preciso neste ponto. Assim, para além da concepção na qual admite-se a liberdade de expressão para insultar outras pessoas e da concepção na qual não se admite isso em prol da dignidade e igualdade de outros grupos minoritários, uma autoritária terceira concepção pode ser criada para, ampliando o conceito de minorias, considerar, falaciosamente, a nação, o Estado ou o grupo ético ou religioso dominante como o grupo a ser protegido em detrimento dos grupos sociais vulneráveis os quais a segunda concepção busca proteger. Nesse cenário, tem-se um forte aparato em prol do regime autoritário, pois a liberdade de expressão é utilizada para proteger o discurso de ódio da maioria poderosa, ou seja, do grupo dominante, na exata medida em que admite o ataque aos grupos minoritários e socialmente vulneráveis, subordinando a liberdade de expressão às ideias antidemocráti$\operatorname{cas}^{72}$. Na realidade brasileira, a utilização de retórica acerca da liberdade de expressão como direito que protegeria a calúnia, injúria, difamação, ameaças e ataques às instituições é um bom exemplo acerca de como o autoritarismo pode se manifestar utilizando-se indevidamente a gramática dos direitos fundamentais, merecendo-se levar a sério a máxima proteção judicial, em termos de uma teoria dos precedentes a partir da democracia militante.

\section{A UTILIZAÇÃO DO PRECEDENTE FIRMADO NA ADPF 572 EM PROL DAS UNIVERSIDADES DIANTE DE SEMELHANÇAS RELEVANTES ENTRE OS CASOS}

O passado pode ser útil para tomada de decisão no presente, sendo esta a base de todas as considerações em torno de um precedente, pois se analisa, precisamente, o que foi decidido anteriormente num caso com semelhanças relevantes. É isso que significa decidir com base em um precedente ${ }^{73}$. Por outro lado, aquele que fixa um precedente, como uma Corte, deve ter a exata noção de que estão exercendo uma função que vai ter impactos no futuro, mostrando que, no final das contas, aplicar um precedente pode acabar tendo uma visão tanto retrospectiva como prospectiva, atraindo a imaginação do juiz em torno das possíveis consequências e novas aplicações da decisão ${ }^{74}$. Nesse exercício prospectivo, a Corte pode adotar formulações linguísticas que restrinjam a aplicação do precedente, mas, como salientando anteriormente e adiante ressaltado, não foi isso que aconteceu no precedente em análise perante o STF.

\footnotetext{
${ }^{71}$ PEREIRA, Anthony W. Ditadura e repressão: o autoritarismo e o Estado de Direito no Brasil, no Chile e na Argentina. Tradução de Patrícia Zimbres. São Paulo: Paz e Terra, 2010. P. 36.

72 TÓTH, Gábor Attila. Ob. cit. p. 58-59.

${ }^{73}$ DUXBURY, Neil. The nature and the authority of precedent. Cambridge: University Press, 2008. p.1.

${ }^{74}$ DUXBURY, Neil. Ob. cit. p. 4.
} 
Para analisar a aplicabilidade do precedente firmado na mencionada ADPF, devese, inicialmente, traçar alguns esclarecimentos sobre qual teoria dos precedentes informará tal análise, pois, dependendo da compreensão que se tenha em torno de questões como a ratio decidendi, ter-se-á uma resposta diferente à indagação posta na introdução. Além disso, deve-se indagar o que é relevante para fins de comparação entre casos, estabelecendo uma análise gradualista em torno da semelhança e diferença entre eles.

A tese ora proposta parte da consideração de que os precedentes podem ser interpretados e serão objeto de desacordo, devendo-se afastar o aguilhão semântico como obstáculo que impede a descrição precisa acerca da prática jurídica como empreendimento interpretativo, pois nega a existência de desacordos sobre os fundamentos do direito ${ }^{75}$. Logo, não se comunga dos ideais em torno de uma estrita garantia de segurança jurídica a partir da aplicação dos precedentes, como supõe Luiz Marinoni ${ }^{76}$.

Em relação à ratio decidendi, diga-se, desde já, que a presente pesquisa parte da compreensão elencada por Neil MacCormick no sentido de que é possível encontrar, na verdade, uma pluralidade de rationes decidendi ${ }^{77}$. É importante estabelecer uma teoria dos precedentes que busque justificações jurídicas bem articuladas, pois o precedente tem uma força normativa considerável na exata medida em que ele comporá justificativas para as novas decisões, apresentando, assim, o referido aspecto normativo que vai influenciar a interpretação ${ }^{78}$.

Essa teoria da justificação jurídica envolve uma importante tarefa a ser desempenhada especialmente pelo juiz no sentido de conferir universalizabilidade ${ }^{79}$ à decisão, ou seja, analisando se a fundamentação por ele desenvolvida num caso poderia ser aplicada a situações assemelhadas, não constituindo, assim, algo meramente particularista. Bustamante também

\footnotetext{
75 DWORKIN, Ronald. Law's empire. Massachusetts: Harvard University Press, 1986. P. 52.

${ }^{76} \mathrm{O}$ autor, desde antes do Código Civil de 2015, já sustentava a necessidade de se levar a sério os precedentes no Brasil, criticando a resistência ou mesmo a indiferença ele relação a eles, fruto da "falsa suposição de que a lei seria suficiente para garantir a segurança jurídica", sendo que, com as diversas interpretações possíveis acerca das leis, a igualdade somente poderia ser alcançada com o respeito aos precedentes (MARINONI, Luiz Guilherme. Precedentes obrigatórios. 6ạ ed. São Paulo: Thomson Reuters Brasil, 2019.p. 8-9). Para o autor, "a força obrigatória dos precedentes é necessária para garantir a coerência da ordem jurídica, a igualdade, a estabilidade e a previsibilidade, além de favorecer a efetividade do sistema de decisões". (MARINONI, Luiz Guilherme. Ob. cit. p. 9) Juraci Mourão responde às teses de Marinoni a partir da constatação, por exemplo, de que os precedentes também podem ser indeterminados, contendo textura aberta. (LOPES FILHO, Juraci Mourão. Os precedentes judiciais no constitucionalismo brasileiro contemporâneo. 2a ed. Salvador: Jus Podivm, 2016. p. 119-128).

77 “Um juiz pode achar necessário formular uma solução em mais de um ponto em questão. Além disso, numa Corte de Apelações, com vários juízes, pode haver várias rationes, e se os juízes produzem votos concorrentes ou dissidentes, diferentes juízes podem tomar diferentes linhas mesmo que em favor da mesma decisão concreta entre as partes do caso. Em alguns casos, muitos juízes podem convergir numa opinião majoritária comum. Em outros, pode ser possível construir uma única solução composta, enquanto produto lógico das muitas rationes dos juízes. Em outros, ainda, não haverá uma ratio comum de um caso julgado por um tribunal colegiado. Haverá um conjunto de soluções possíveis para a questão, cada uma com justificativas que a apóiam como a melhor para este caso e outros semelhantes. Pode-se dizer que, se todas oferecidas são mutualmente consistentes, todas deveriam ser seguidas aos menos no sentido de não serem contraditadas no futuro. Isso provavelmente não permitirá, porém, muita coerência ao longo do tempo e, nesse sentido, todas devem ser consideradas persuasivas, e cortes futuras serão livres para desenvolver qualquer uma à luz de novas considerações". (MACCORMICK, Neil. Retórica e estado de direito. Tradução de Conrado Hübner Mendes. Rio de Janeiro: Elsevier, 2008. P. 203204).
}

78 MACCORMICK, Neil. Ob. cit. p. 192.

${ }^{79}$ MACCORMICK, Neil. Ob. cit. p. 197. 
Ódio ao STF e às Universidades Públicas: aplicação da ADPF 572 (caso das fake News) para proteção da comunidade acadêmica

sustenta ideia semelhante, pois o precedente somente será padrão decisório se for possível elaborar uma regra com pretensão de universalidade, ou seja, possibilidade de aplicação a todos os casos semelhantes, como uma garantia de imparcialidade na atuação judicial não sendo exercida de acordo com o réu, por exemplo ${ }^{80}$. O ideal em torno da universalizabilidade é de suma importância para a tese ora desenvolvida neste texto, pois negar a proteção das Universidades contra notícias fraudulentas equivaleria a transformar o precedente firmado na APDF 572 em fonte marcadamente particularista, servindo, unicamente, para a proteção do Poder Judiciário.

Não pode haver dúvidas acerca da essencialidade das Universidades para a democracia brasileira sendo tal tema objeto de atenção pela doutrina, tendo em vista, precisamente, o cenário autoritário já narrado anteriormente, o qual desafia a reafirmação da autonomia universitária ${ }^{81}$. Num Estado Social como o brasileiro, o ensino público é ainda mais essencial como ferramenta de inclusão social, devendo as respectivas instituições serem protegidas para que se evite que uma massa de pessoas pobres não tenha o direito de estudar. Logo, a essencialidade das Universidades para uma democracia que garanta direitos sociais é bastante forte, merecendo ser conferido a elas a mesma proteção garantida ao STF a partir do caso das fake news.

Nessa linha, de acordo com a 5 a Pesquisa Nacional de Perfil Socioeconômico e Cultural dos Graduandos das Instituições Federais de Ensino Superior de 2018, tem-se que 53\% dos graduandos das referidas instituições estão na faixa de renda mensal familiar per capita de "até um salário mínimo" e 70,2\% na faixa de renda mensal per capita de "até um salário mínimo e meio" 82 . É certo que, como destacado na própria pesquisa, não se trata da camada mais pobre da população, já que "os setores mais pobres e miseráveis nem mesmo chegam a concluir o Ensino Médio ${ }^{83 "}$ mas os percentuais acima apontam com segurança para o papel de inclusão da universidade em relação a estratos sociais que, certamente, teriam dificuldades em cursar uma universidade particular.

A situação antes descrita acerca das ameaças sofridas pelos Ministros do STF não é muito diferente daquela vivenciada por pesquisadores brasileiros, os quais têm, até mesmo, se exilado em face de ameaças de morte. Nesse sentido, matéria do jornal Correio Brasiliense informa que "desde 2017, pelo menos 41 acadêmicos brasileiros que se sentem inseguros buscaram ajuda da organização sem fins lucrativos Scholars at Risk (SAR), com sede na New York University. Entre setembro de 2019 e o presente momento, foram seis casos" ${ }^{84}$.

De acordo com o relatório Free to Think, diversos tipos de ataques violentos tem ocorrido no ambiente acadêmico brasileiro: a) em 10 de outubro de 2018, atos de racismo foram

\footnotetext{
${ }^{80}$ BUSTAMANTE, Thomas. Teoria do precedente judicial. A justificação e a aplicação de regras jurisprudenciais. São Paulo: Noeses, 2012. p. 112-113.

${ }^{81}$ MEYER, Emilio; BUSTAMANTE, Thomas; BATISTA JÚNIOR, Onofre Alves. Ob. cit. p. 279.

82 BRASIL. ANDIFES. $5^{\text {a }}$ Pesquisa Nacional de Perfil Socioeconômico e Cultural dos Graduandos das Instituições Federais de Ensino Superior de 2018. Disponível em: http://www.andifes.org.br/wpcontent/uploads/2019/05/V-Pesquisa-Nacional-de-Perfil-Socioecon\%C3\%B4mico-e-Cultural-dos-asGraduandos-as-das-IFES-2018.pdf. Acessado em: 03/08/2020. P. 31.

83 Ibidem.

84 CORREIO BRASILIENSE. Acadêmicos brasileiros se exilam por ameaças de morte. Disponível em: https://www.correiobraziliense.com.br/app/noticia/eu-estudante/ensino_ensinosuperior/2020/03/13/internaensinosuperior-2019,834162/academicos-brasileiros-se-exilam-por-ameacas-de-morte.shtml. Acessado em: 07/06/2021.
} 
praticados contra aluna negra na Universidade de Fortaleza (UNIFOR), a qual chegou a ser estuprada; b) em 19 de outubro, seis indivíduos não identificados atacaram grupo de estudantes que estavam distribuindo material de campanha favorável ao então candidato Fernando Haddad, sofrendo ainda ameaças de morte em praça próxima ao campus da Universidade Federal do Rio de Janeiro; c) em 31 de outubro de 2018, representantes estudantis da Universidade Federal do Pará receberam ameaças anônimas fazendo referência ao "extermínio" de estudantes LGBTQ+; d) em 07 de novembro, uma carta anônima circulou na Universidade Federal de Pernambuco declarando que, quando Jair Bolsonaro fosse eleito, um grupo de cerca de 20 estudantes seriam expulsos, sendo tal grupo conhecido pelas pesquisas na área LGBTQ $+{ }^{85}$.

Um dos casos mais famosos de violência contra acadêmicos refere-se à professora Debora Diniz, a qual conduz pesquisa sobre aborto e, em 2018, precisou deixar o Brasil diante de ameaças de morte contra ela, membros da família e alunos ${ }^{86}$. A pesquisadora foi expressamente citada pelo Presidente Jair Bolsonaro em postagem no twitter, tendo atraído o forte ataque de "milícias digitais" que praticaram contra ela diversos crimes conta a honra e ameaças, como relatado por ela mesma em mensagem na rede social ${ }^{87}$.

Além disso, as Universidades tem sido alvo de notícias fraudulentas. Além da fala em torno da "balbúrdia", o então Ministro da Educação Abraham Weintraub chegou a sustentar que existiam "extensivas plantações de maconha" nas áreas das instituições de ensino públicas, tendo a União sido condenada a pagar danos morais coletivos diante de tais falas em ação movida pela União Nacional dos Estudantes ${ }^{88}$. Mostrando como a prática autoritária da cúpula desenvolve-se difusamente, tem-se o empoderamento de diversos agentes sociais que comungam ideias semelhantes em relação às universidades, utilizando a liberdade de expressão para difamar e discriminar alunos e professores de tais instituições nas mais diversas regiões do País ${ }^{89}$.

\footnotetext{
${ }^{85}$ SCHOLARS AT RISK. Free to think. Report of the scholars at risk academic freedom monitoring project. New York University, 2019. P. 56

86 CORREIO BRASILIENSE. Acadêmicos brasileiros se exilam por ameaças de morte. Disponível em: https://www.correiobraziliense.com.br/app/noticia/eu-estudante/ensino_ensinosuperior/2020/03/13/internaensinosuperior-2019,834162/academicos-brasileiros-se-exilam-por-ameacas-de-morte.shtml. Acessado em: 07/06/2021.

87 Debora Diniz assim relata: “Montei vocabulário bolsonarista em 24 horas de redemoinho do ódio: 'Feminista fedorenta, esquerdopata, feminaze, sovaco cabeludo, cara de fuinha, cara de maracujá, cara de gente chata, chata, tem chato, velha e velha (muito velha), puta velha, feia, estúpida, horrorosa, assassina, pedófila, seca, mal comida, mal amada, deveria ter sido abortada, cheira a bacalhau, vai morrer empalada, vou matar você, me espere na esquina, sei onde você mora, abortista, cretina, miserável, medonha, desprezível, mulheres e homens do mundo ataquem!, demoníaca, belzebu, vai morar na Venezuela/Coreia/Cuba, mentirosa, puta, sapatão, bafenta, com chulé e caspa, nojenta, feia, côco e estrume, criminosa, inútil, invejosa, queria ser princesa, mas não é, queria ser Damares, mas não é, não brincou de boneca, deve ter gostado de Scania oportunista, mentirosa, não tem marido, a mãe devia ter abortado, aproveitadora, por que não divide o dinheiro, socialista-comunistado PT, votou no PSOL, satanista, o revolver para descarregar na sua cara, quer proteger pedófilo, desocupada, parasita, vou contar para sua mãe+ você queria ter casado com nosso presidente, côco de diarréia, vou dar um tiro na sua cabeça, defensora de pedófilos" (TWITTER, 2021)

${ }^{88}$ BRASIL. 26a . Vara Federal de São Paulo. Ação civil pública 5025911-73.2019.4.03.6100.

${ }^{89}$ Veja-se, por exemplo, o caso do ex-candidato a Deputado Estadual pelo PSL do Rio Grande do Norte Daniel Sampaio, o qual em 07/05/2020, apenas alguns dias após Weintraub ter emitido a fala sobre a "balbúrdia", proferiu a seguinte declaração em relação às universidades federais no programa Cenário Político, veiculado pelo canal TCM Mossoró: "Esse corte de 30\% foram causados pelos própria universidades federais porque elas não
} 
Ódio ao STF e às Universidades Públicas: aplicação da ADPF 572 (caso das fake News) para proteção da comunidade acadêmica

Mas é preciso retomar a ideia em torno das possíveis restrições ao uso do precedente firmadas preventivamente pela Corte quando da formação daquele. O precedente pode apresentar o que Frederick Schauer denomina de "caracterização articulada", o que corresponde à linguagem canônica utilizada para firmar as rationes decidendi, facilitando a busca por similaridades relevantes com casos futuros ${ }^{90}$. Assim, a decisão pode adotar uma linguagem na qual já se restrinja a utilização do precedente, como se fosse uma regra a qual, obviamente, poderia ser superada, mas se exigindo maior ônus argumentativo ${ }^{91}$. Por exemplo, caso o STF tivesse adotado linguagem vinculando os perigos em torno da utilização das fake news, unicamente, em face da atuação dos juízes, diante de alguma particularidade em tal função, seria mais difícil sustentar a aplicação do precedente para casos envolvendo notícias fraudulentas contra as universidades, como se pretende demonstrar neste momento. No entanto, como elencado anteriormente, o STF, em momento algum, adotou tal caracterização canônica restritiva, assentando, por outro lada, o perigo de tal prática para a democracia como um todo.

A caracterização articulada é muito importante para evitar más utilizações dos precedentes, quando, por exemplo, tem-se que o banimento de discurso de ódio nazista possa ser utilizado para banir discursos socialistas, mesmo diante das profundas diferenças entre os

fizeram prestações de contas. O que é prestação de contas? Eu, por exemplo, faço parte da Associação de Psiquiatria e da Associação Norte Rio-Grandense e ano passado tentamos realizar um evento lá em Natal, a jornada de psiquiatria e eu fui pedir um evento à Universidade que eu estudei, a UFRN, fui pedir um evento aonde meus amigos são professores da UFRN e não tinha recurso. Mas no mesmo dia em Natal se realizou um evento para se discutir as vantagens da liberação da maconha para a minha grande surpresa e tristeza existia recurso para esse evento onde conversaram sobre a liberação da maconha. Então, o que está sendo feito com esse dinheiro? O governo, eu quero essa explicação. Porque o meu evento é um evento científico onde vinha a nata, as maiores autoridades da psiquiatria do Brasil para Natal e não teve recurso. Então, o que as Universidades estão fazendo com esse dinheiro?

A questão da manifestação cultural, nós temos de definir o que é cultura. Não são peças de Shakespeare que nós vemos nas universidades. A gente vê o "bundaço", o "vomitaço", uma coisa tão esquisita aquilo não é cultura e eu fiquei muito preocupado porque hoje eu estou

Eu estou como médico psiquiatra estou acompanhando os alunos que estão saindo das universidades federais, eu atendo pessoas do Ceará, da Paraíba, aqui do Rio Grande do Norte e eu estou acompanhando hoje jovens que entraram na universidade pensando no seu futuro sem nenhuma dependência química, sem nenhuma tatuagem, e estão saindo cheios de tatuagens com dependências químicas, principalmente em álcool e maconha, doenças mentais graves. Jovens que às vezes eu preciso internar. Isso é um alerta aos pais: se minha filha fosse aprovada numa universidade federal, eu não deixaria ela cursar, porque eu me preocupo com isso, eu vejo o sofrimento, os pais entrando em depressão, os jovens pensando em suicídio, no ambiente universitário o índice de suicídio aumentou muito e a gente precisa observar isso com muito cuidado. Essas manifestações culturais, essa permissividade que hoje acontece nas universidades federais tem de te algum freio e eu acho que não é só a partir dessa limitação de recursos. Tem que haver uma proibição mais rígida como a polícia, que tem de ter acesso às universidades. A gente viu um arrastão aqui nas universidades de Mossoró aonde os alunos preferiram ter o celular roubado do que permitir que a polícia entrasse. Então isso está errado, a gente precisa criar um ambiente saudável para as nossas futuras gerações." (SIC). BRASIL. Ministério Público Federal. Procuradoria da República no Município de Mossoró. Procedimento Preparatório no 1.28.100.000079/2020-66. Tal fala alberga três condutas geradoras de dano moral aos alunos e professores em face de generalizações nas quais, dolosa e falsamente: a) atribui-se a não prestação de contas aos professores gestores das Universidades Federais; $b$ ) supõe-se que alunos das universidades federais são pessoas viciados em drogas; c) valora-se, negativa e preconceituosamente, o aluno que usa tatuagens. Os fatos estão relacionados ao contexto da guerra cultural contra o ensino público, mostrando uma visão autoritária de cultura pelo réu, ante o pensamento de que somente há uma visão de mundo possível numa esfera pública marcada pelo pluralismo.

90 SCHAUER, Frederick. Precedent. Stanford Law Review. Vol. 39, № 3. Feb. 1987. p. 571-605. p. 579.

${ }^{91}$ SCHAUER, Frederick. Ob. cit. p. 580-581. 
casos. Para superar esse temor, basta a corte produzir o precedente com o mencionado cuidado linguístico, articulando precisamente a caracterização dos fatos relevantes ${ }^{92}$. Essa é uma tarefa importante, também, a ser desempenhada pela parte que pretende a formação do precedente nesse cenário de risco autoritário e polarizado, pois, ao invés de, simplesmente, adotar posição pusilânime temendo possíveis e incertas aplicações do precedente, pode engajarse ativamente para que a corte caracterize bem o caso, diminuindo o risco em torno aplicações indevidas. Diz-se que o risco é diminuído porque, realisticamente, nada impede que um juiz tome uma decisão completamente equivocada, como que "corrompendo" um precedente. No entanto, se assim o fizer, seu ônus argumentativo será muito maior, sendo tal decisão alvo de provável reforma.

Deve-se, destacar, repita-se, que, a partir da análise cuidadosa dos votos lançados na ADPF 572 , como efetivado acima, não se constata qualquer restrição expressa, por parte dos Ministros, acerca da aplicação futura do precedente no contexto restrito de ataques em relação ao Poder Judiciário ou, mais especificamente, ao STF. Sem dúvidas, a Corte poderia ter adotado tal expediente, mas não o fez. Logo, interpretando as diversas razões de decidir nele contidas a partir da democracia militante expressamente nele consignada, é possível concluir com segurança que elas podem ser utilizadas contra quaisquer disseminações de notícias falsas contra instituições democráticas, sendo uma questão de grau analisar a força da aplicação dessas razões.

Cabe ao Poder Judiciário, como se sabe, aplicar os precedentes de maneira coerente, além de íntegra. Interpretando o precedente a partir das tarefas em torno da democracia militante, como expressamente consignada pelos Ministros Edson Fachin e Gilmar Mendes, além de implicitamente constante nos demais votos, tem-se que, repita-se, a razão central da decisão vocaciona-se à proteção da democracia. Ora, seria altamente incoerente admitir a necessidade de salvaguardar o STF contra tais práticas e negar tratamento semelhante a outra instituição igualmente importante para o regime democrático como são as universidades.

Há, ainda, ganho hermenêutico na proposta ora defendida a partir do enriquecimento do sistema jurídico, adicionando-se sentido ao Direito ${ }^{93}$. Os precedentes, tendo a característica de ser uma decisão isolada que servirá como padrão para casos futuros, pode apresentar um ganho hermenêutico mais acentuado justamente no bojo do controle concentrado de constitucionalidade, pois questões complexas e específicas, muitas vezes, são levadas à Corte para a tomada de decisão sem qualquer precedente próximo. Em outras palavras: trata-se de caso único, mas possivelmente o primeiro de muitos outros semelhantes, realçando a importância de uma das funções mais significativas do precedente, que é, justamente, propiciar o mencionado enriquecimento.

\footnotetext{
92 SCHAUER, Frederick. Ob. cit. p. 581.

${ }^{93}$ LOPES FILHO, Juraci Mourão. Ob. cit. p, 339-340. O exemplo apresentado pelo autor refere-se ao julgamento da ADI 3510, no contexto dos limites das pesquisas com células tronco embrionárias: como a Lei 11.105/05 não apresentara disposição fixando precisamente o momento em que se considera iniciada a vida, e como o texto constitucional limita-se a elencar a "inviolabilidade do direito à vida", foi necessário, para além da lei, a formação de precedente judicial que esclarece mais ainda os pontos controvertidos, apontando que as referidas normas constitucionais e legais protegeriam as células tronco apenas no casos de embriões viáveis, não alcançando aqueles congelados. Essa adição de sentido é, precisamente, o ganho hermenêutico. Sustento que também há ganho hermenêutico quando um precedente é interpretado e aplicado à situação assemelhada, muito embora, realmente, não haja o mesmo grau de inovação quando considerada a primeira decisão.
} 


\section{CONSIDERAÇÕES FINAIS}

Respondendo à indagação posta na introdução, é possível concluir que sim, o precedente firmado na ADPF 572 deve ser aplicado na proteção das Universidades no contexto de disseminação de fake news contra elas, especialmente quando se pratica crimes contra professores e alunos, bem como através das respectivas notícias falsas, como exemplificado no texto.

As diferenças entre os casos, relacionadas às particularidades institucionais do Poder Judiciário e das Universidades no contexto o ensino público não são relevantes quando se interpreta as razões de decidir do caso a partir da democracia militante, como expressamente consignada nos Votos dos Ministros Edson Fachin e Gilmar Mendes e implicitamente nos demais votos vencedores. Essa foi uma das razões mais fortes para formação do precedente: a proteção do regime democrático atacado por notícias falsas e, nesse sentido, como as Universidades ostentam caráter essencial para a democracia brasileira, tratamento diferenciado seria profundamente incoerente.

A semelhança entre os casos é ainda mais evidente quando se constata que o contexto de tais ataques é o mesmo, relacionado ao desenvolvimento do autoritarismo populista no Brasil, o qual, como visto, apresenta como uma de suas pautas contra as instituições a proscrição ao intelectualismo. Visto dessa forma, o presente texto pode ser lido também como uma manifestação de novas pautas em torno da democracia militante, a qual busca, por exemplo, potencializar os instrumentos institucionais, no caso, um precedente, em prol da manutenção do regime democrático.

Como tal argumentação não se quer sustentar que os precedentes sejam a principal fonte da juridicidade, consideração que poderia ser levantada tendo em vista a centralidade de tal fonte para esta pesquisa. Juízes devem interpretar os demais enunciados normativos necessários para a tomada de decisão e analisar a compatibilidade dos precedentes em relação a tais interpretações. Tendo em vista um objetivo prático na atuação processual e na tomada de decisão judicial, no entanto, não se pode negar que a demonstração da aplicação de um precedente em prol de determinada demanda aumenta a chance de sucesso. Quando se busca uma aplicação íntegra do precedente, tem-se mais um argumento em torno da sua correição.

\section{REFERÊNCIAS}

BUSTAMANTE, Thomas. Teoria do precedente judicial. A justificação e a aplicação de regras jurisprudenciais. Noeses: São Paulo, 2012.

CAMPOS, Francisco. O estado nacional. Coleção Biblioteca Básica Brasileira. Brasília: Senado Federal, Conselho Editorial, 2001. 
CASARA, Rubens R. R. O estado pós-democrático: neo-obscurantismo e gestão dos indesejáveis. Rio de Janeiro: Civilização Brasileira, 2017. Kindle Edition.

CORREIO BRASILIENSE. Acadêmicos brasileiros se exilam por ameaças de morte. Disponível em: https://www.correiobraziliense.com.br/app/noticia/eu-estudante/ensino_ensinosuperior/2020/03/13/interna-ensinosuperior-2019,834162/academicos-brasileiros-se-exilampor-ameacas-de-morte.shtml. Acessado em: 07/06/2021. 2020.

DWORKIN, Ronald. Law's empire. Massachusetts: Harvard University Press, 1986.

DUXBURY, Neil. The nature and the authority of precedent. Cambridge: University Press, 2008.

FERRAJOLI, Luigi. Poderes selvagens. A crise da democracia italiana. Tradução de Alexander Araujo de Souza. São Paulo: Saraiva, 2014.

FINCHELSTEIN, Federico. Do fascismo ao populismo na história. Tradução Jaime Araújo. São Paulo: Almedina, 2019. Kindle edition.

GINSBURG, Tom; HUQ, Aziz Z.; How to save a constitutional democracy. Chicago; London: The University of Chicago Press, 2018.

GROSS, Clarissa Piterman. Fake news e democracia: discutindo o status normativo do falso e a liberdade de expressão. In.: RAIS, Diogo (org.). Fake news - a conexão entre a desinformação e o direito. 2o ed. São Paulo: Thomson Reuters Brasil, 2020.

LOPES FILHO, Juraci Mourão. Os precedentes judiciais no constitucionalismo brasileiro contemporâneo. 2a ed. Salvador: Jus Poddivm, 2016.

LOEWENSTEIN, Karl. Militant democracy and fundamental rights I. The American political science review. Vol. XXXI. № 3. Jun. 1937A.

MACCORMICK, Neil. Retórica e estado de direito. Tradução de Conrado Hübner Mendes. Rio de Janeiro: Elsevier, 2008.

MARINONI, Luiz Guilherme. Precedentes obrigatórios. 6a ed. São Paulo: Thomson Reuters Brasil, 2019.

MEYER, Emílio Peluso Neder. Judges and Courts Destabilizing Constitutionalism: The Brazilian Judiciary Branch's Political and Authoritarian Character. German Law Journal. Vol. 19 , ed. 4. 2018. p. 727-768.

MEYER, Emilio; BUSTAMANTE, Thomas; BATISTA JÚNIOR, Onofre Alves. Autonomia universitária, democracia e federalismo. Revista Culturas Jurídicas. Vol. 6, Núm. 13, jan./abr., 2019.

MÜLLER, Jan-Werner. Militant democracy. In: ROSENFELD, Michel; SAJÓ, András. (ed.). The Oxford Handbook of Comparative Constitutional Law. Oxford: Oxford University Press, 2012, p. $1253-1269$.

MÜLLER, Jan-Werner. Populism and constitutionalism. In: OSTIGUY, Pierre el al (ed.). The Oxford Handbook of Populism. Oxford: Oxford University Press, 2017.

PEREIRA, Anthony W. Ditadura e repressão: o autoritarismo e o Estado de Direito no Brasil, no Chile e na Argentina. Tradução de Patrícia Zimbres. São Paulo: Paz e Terra, 2010.

RIJPKEMA, Bastiaan. Militant democracy. The limits of democratic tolerance. London, New York: Routledge, 2018. 
Ódio ao STF e às Universidades Públicas: aplicação da ADPF 572 (caso das fake News) para proteção da comunidade acadêmica

SCHOLARS AT RISK. Free to think. Report of the scholars at risk academic freedom monitoring project. New York University, 2019.

SCHAUER, Frederick. Precedent. Stanford Law Review. Vol. 39, № 3. Feb. 1987. p. 571-605.

STANLEY, Jason. Como funciona o fascismo: a política do "nós" e "eles". Tradução de Bruno Alexander. São Paulo: L\&PM, 2018.

TUSHNET, Mark. Authoritarian constitutionalism. Cornell Law Review. Vol. 100. P. 391-462. 2015.

TÓTH, Gábor Attila. Constitutional Markers of Authoritarianism. Hague Journal on the Rule of Law, v. 11, n. 1, 2019.

TWITTER. Debora Diniz. "Vocabulário bolsonarista". Disponível em: https://twitter.com/debora_d_diniz/status/1358467321308798976. Acessado em: 08/06/2021. 07/02/2021. 